ACTA

AMAZONICA

\title{
Podridão-mole em plantas de cebolinha causada por Pectobacterium carotovorum subsp. carotovorum em Roraima
}

\author{
Bernardo A. HALFELD-VIEIRA ${ }^{1}$, Kátia de Lima NECHET ${ }^{2}$ \\ RESUMO \\ A ocorrência de Pectobacterium carotovorum subsp. carotovorum (=Erwinia carotovora subsp. carotovora) em cebolinha (Allium \\ fistulosum) é relatada pela primeira vez na regiāo norte do Brasil. Até então sua ocorrência estava registrada apenas no Distrito \\ Federal. \\ PalaVRAS-CHAVE: Allium fistulosum; Pectobacterium carotovorum subsp. carotovorum; Erwinia carotovora subsp. carotovora; \\ podridão-mole; Etiologia.
}

\section{Soft rot of bunching onion plants caused by Pectobacterium carotovorum subsp. carotovorum in Roraima, Brazil}

\section{ABSTRACT}

This is the first report of Pectobacterium carotovorum subsp. carotovorum (=Erwinia carotovora subsp. carotovora) causing soft rot of bunching onion (Allium fistulosum) plants in Roraima, Brazil. Its occurrence is reported only in Distrito Federal.

KEY WORDS: Allium fistulosum; Erwinia carotovora subsp. carotovora; soft-rot; Amazon; Etiology.

${ }_{1}^{1}$ Pesquisador da Embrapa Roraima, Ds. Fitopatologia, halfeld@cpafrr.embrapa.br

2 Pesquisador da Embrapa Roraima, Ds. Fitopatologia, katia@cpafrr.embrapa.br 
A cebolinha (Allium fistulosum L.) é amplamente cultivada por agricultores familiares do cinturão verde de Boa Vista, Roraima, constituindo importante fonte de renda.

Em visitas realizadas em campos de produção em fevereiro de 2005 foram observadas plantas de cebolinha mortas, com sintomas de podridão-mole, resultando em significativa redução do stand (Figura 1).

No material coletado foi verificada abundante exsudação bacteriana na região entre o tecido afetado e sadio. $\mathrm{O}$ isolamento da bactéria foi realizado em meio 523 (Kado \& Heskett, 1970). Para testes de patogenicidade foram utilizadas plantas cultivadas em copos de $500 \mathrm{ml}$, realizando-se dois métodos de inoculação: A) deposição de $50 \mu \mathrm{l}$ da suspensão bacteriana ajustada a $10^{8}$ ufc. $\mathrm{ml}^{-1}$ sobre folha cortada transversalmente, mantendo-se em câmara úmida por $24 \mathrm{~h}$; B) por injeção com seringa de $50 \mu \mathrm{l}$ da suspensão na base da planta. Como controle utilizou-se somente água destilada esterilizada. Para cada tratamento foram utilizadas 10 plantas perfilhadas.

Após oito dias foram observados os primeiros sintomas nas plantas inoculadas pelo método $\mathrm{A}$, evoluindo rapidamente. Nas plantas inoculadas pelo método $B$ houve morte de plantas em um período de até $72 \mathrm{~h}$ (Figura 2). Em ambos os casos a bactéria foi reisolada. Não foram observados sintomas nos tratamentos em que houve deposição de água destilada esterilizada.

A identificação do patógeno foi realizada baseando-se em critérios estabelecidos descritos em literatura específica (Fahy \& Presley, 1983; Goto, 1992; Klement et al., 1990; Schaad et al., 2001). Os resultados observados na sua caracterização foram: bactéria Gram-negativa, com células em forma de bastonete, não esporogênica, com atividade pectinolítica, anaeróbia facultativa, com resultado positivo para catalase, crescimento a $37^{\circ} \mathrm{C}$ e em $\mathrm{NaCl}$ a $5 \%$. Produção de ácido

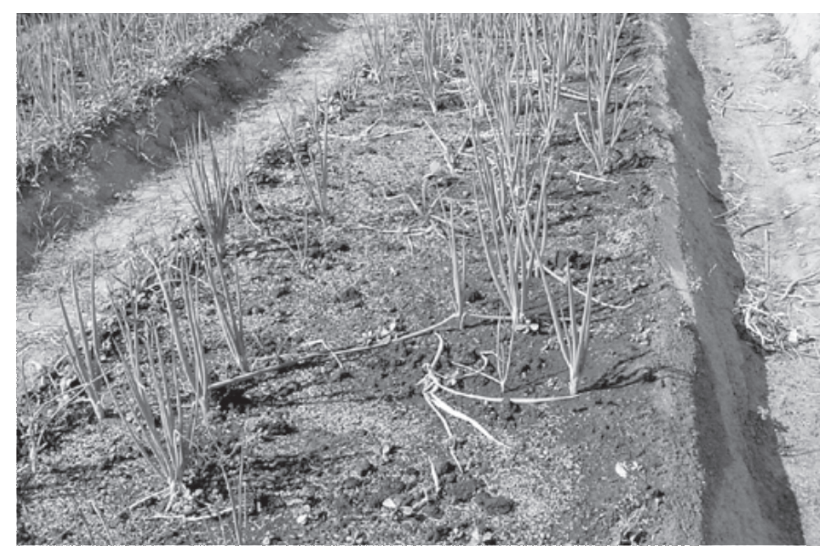

Figura 1- Redução do stand causada por mortalidade de plantas infectadas por $P$. carotovorum subsp. carotovorum.

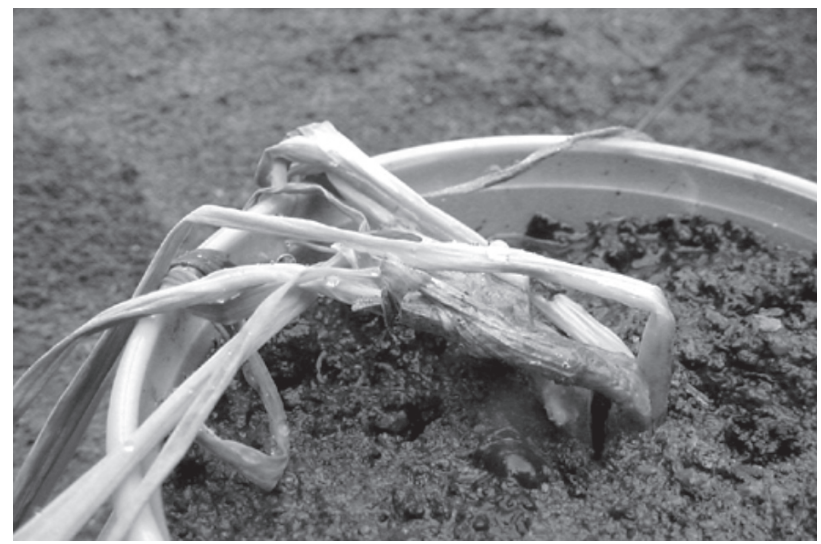

Figura 2 - Podridão-mole em planta de cebolinha inoculada com suspensão de células de $P$. carotovorum subsp. carotovorum.

a partir de melibiose, lactose e citrato, e não por sorbitol. Resultado negativo para oxidase, hidrólise do Tween 80, urease, substâncias redutoras a partir de sacarose e sensibilidade à eritromicina.

Os resultados permitiram identificar a bactéria Pectobacterium carotovorum subsp. carotovorum (Jones 1901) Hauben et al. 1999 como agente causal da podridão-mole em cebolinha. No Brasil, esta subespécie é reportada em cebolinha apenas no Distrito Federal, enquanto Pectobacterium chrysanthemi (Burkholder et al. 1953) Brenner et al. 1973 constitui a espécie de maior ocorrência no país (Marques et al.,1994).

\section{BIBLIOGRAFIA CITADA}

Fahy, P.C.; Presley, G.J. 1983. Plant bacterial diseases - a diagnostic guide. Academic Press, San Diego, 393pp.

Goto, M. 1992. Fundamentals of bacterial plant pathology. Academic Press, San Diego. 342pp.

Kado, C.I.; Heskett, M.G. 1970. Selective media for isolation of Agrobacterium, Corynebacterium, Erwinia, Pseudomonas and Xanthomonas. Phytopathology, 60 (6): 969-976.

Klement, Z.; Rudolph, K.; Sands, D.C. (Eds.). 1990. Methods in phytobacteriology. Akadémiai Kiadó, Budapest. 568pp.

Marques, A.S.A.; Robbs, C.F.; Boiteux, L.S.; Parente, P.M.G. 1994. Indice de fitobacterioses assinaladas no Brasil. Embrapa, Brasília. $65 \mathrm{pp}$.

Schaad, N.W.; Jones, J.B.; Chun, W. (Eds.). 2001. Laboratory guide for identification of plant pathogenic bacteria. APS, St. Paul, $3^{\text {a }}$. ed., 373pp.

Recebido em 26/10/2006

Aceito em 9/05/2008 